1991

\title{
Legal Resources of Striking Miners: Notes For a Study of Class Conflict and Law
}

Frank W. Munger

New York Law School, frank.munger@nyls.edu

Follow this and additional works at: http://digitalcommons.nyls.edu/fac_articles_chapters

Part of the Law and Society Commons

\section{Recommended Citation}

15 Social Science History 1 (1991)

This Article is brought to you for free and open access by the Faculty Scholarship at DigitalCommons@NYLS. It has been accepted for inclusion in Articles \& Chapters by an authorized administrator of DigitalCommons@NYLS. 


\section{Legal Resources of Striking Miners: Notes for a Study of Class Conflict and Law}

FRANK MUNGER

Union miners stand together,

Heed no operator's tale.

Keep your hands upon the dollar,

And your eyes upon the scale.

—verse from "Miner's Lifeguard" [Silverman I975: 389]

IN I895, Fayette County, West Virginia, a leading coal county in the southern West Virginia coal fields, experienced widespread strikes by miners. The strikes were remarkable because, in an American industry known for violent labor relations and intensive union organizing since the appearance of the Molly Maguires in Pennsylvania before $\mathrm{I} 880$, this was the first major strike in southern West Virginia. We might attempt to understand the role of law and public authority in these strikes in terms of legal repression by means of the labor injunction, labor conspiracy laws, and strikebreaking by the police and military. But none of these occurred in Fayette in I895, though the later history of labor conflict in West

Frank Munger is professor of law at the State University of New York at Buffalo. He gives particular thanks to Jim Atleson, Fred Konefsky, and Carroll Seron for reading drafts of the manuscript of this article. An earlier version was presented to the New York University Faculty Seminar on Law and Social Science, to whose participants the author is grateful for their insightful discussion. This article was supported in part by an Appalachian Studies Fellowship from Berea College and by National Science Foundation grant SES-8I 21320.

Social Science History 15: I (Spring 199I). Copyright (C) I99I by the Social Science History Association. Ccc 0I45-5532/9I/\$I.50. 
Virginia is replete with all of them. In another way, however, the legal events accompanying these strikes are far more remarkable and challenge us to examine more subtle connections between class conflict and law.

In this essay I examine litigation in conflicts between two groups of actors, coal miners and coal mine owners, in Fayette County between 1872 and 1925 . I attempt to determine whether and how the demand for this form of intervention by public authorities changed and to understand the reasons for the changing reliance on law in instances of conflict between these two classes of actors. I begin by describing the strikes and their failure. I then describe parallel events that suggest a connection between strikes and other events, including litigation by miners, that resulted in the mobilization of public authority. Building on the suggested relationship between collective action and changes in the demand for state intervention, I sketch a theoretical framework for understanding the role of law in class conflict in the specific historical context of the Progressive Era.

Theory holds that the American state was transformed in response to demands that were engendered by a developing national economy. Although conflict or conflict resolution between miners and mine owners in West Virginia may have been shaped in part by the unique structure of the coal industry or the local politics of Fayette County, the changing demands of local actors on public authority and the consequences of the use of public authority for the continuing class relations of those actors are an instance of the process by which the American state was transformed generally during the Progressive Era. Drawing on my longitudinal and historical research on litigation and social change in southern West Virginia, I provide illustrations of the process by which collective action by workers led not only to immediate intervention by public authorities but also to more subtle, less predictable employment of law to reinforce the market and to control class conflict and change. ${ }^{1}$

THE FAILURE OF FAYETTE COUNTY MINERS'

STRIKES, I895-I902

In the coal fields of Ohio, Indiana, Illinois, and Pennsylvania, unions and employers were moving toward industrywide bargain- 
ing as early as I885 (Thomas I97I: 233). Among the major eastern coal-producing states, West Virginia alone remained unorganized. In the late I88os, the Kanawha coal field west of Fayette County was represented at conferences with other midwestern miners to discuss wage scales, but the New River field, which included Fayette County, was not. Operators negotiating with organized miners in other states were supportive of the efforts of the United Mine Workers of America (UMWA) to organize West Virginia miners. In I894 a UMWA strike for higher wages throughout the midwestern coal fields failed in large part because West Virginia mines kept producing.

In I895 a protracted struggle between West Virginia operators and the bankrupt Norfolk and Western Railroad climaxed five years of steady decline in miners' wages. Operators were eventually forced to accept the railroad's less favorable terms for shipping coal, but miners in the New River coal field remained out on strike, led by militant black West Virginia miners who refused to compromise wage demands. The UMWA used this occasion as the opening wedge for an organizing campaign. This campaign failed to win concessions in spite of the fact that the governor repeatedly refused to order militia into the area. Miners returned to work at a lower wage. When the UMWA called for a strike throughout the Midwest in 1897, the southern West Virginia miners did not respond. Intensive efforts by UMWA organizers to improve upon the initial failure in the region produced a weak response: in I897 less than one-third of Fayette's miners left work in response to the union's call, and by 1898 fewer than $4 \%$ were still striking (West Virginia Department of Mines 1897, I898). Operators pursued UMWA organizers with a sweeping injunction against organizing issued by the Federal District Court for the Southern District of West Virginia (Thomas 197I: 246).

Union organizing in Fayette County reached a climax in 1902 and 1903. John Mitchell assumed the presidency of the union in I899 on a platform committing him to organizing West Virginia miners. The strikes in 1902 and 1903 were of a magnitude not approached by previous or subsequent efforts of the union in southern West Virginia. More than 80 mines in Fayette County alone were struck for recognition of the UMWA. This time the operators turned to the state for armed support at the first sign of violence. A troop of militia was ordered into the area by the gov- 
ernor to back up measures taken by the operators under the private law, including evicting miners from housing and barring access to local water supplies (ibid.: 258). The Federal District Court obliged the operators with an injunction barring the provisioning of strikers by the UMWA. The Norfolk and Western Railroad aided the operators by transporting strikebreakers to the mines. As the strike began to fail, an armed posse led by a federal marshall surrounded 200 miners at Stanaford in neighboring Raleigh County, killing 3 and wounding several hundred in the fight that followed an attempted arrest. ${ }^{2}$

These failed strikes left a legacy of hostility between miners and owners. Indeed, it has been argued that the strikes of 1902 and 1903 never really ended (ibid.). Violence continued long after the strikers had been replaced by black and foreign-born miners and long after the strikes had virtually come to an end. Two months after the Stanaford violence, James Harless, a strike leader, was shot and killed by coal operator James Laing, a member of the posse that had surrounded the house in which Harless was hiding. ${ }^{3}$ Continuing threats on the lives of leading coal operators were reported by Fayette papers. Their bitterness established a pattern that persisted in labor relations in southern West Virginia for many years. Not only were striking miners replaced by black and immigrant workers who were brought to southern West Virginia by the operators, but operator resistance stiffened: the Southern Coal Operators Association was formed to oppose union organizing; a brutal private police force was employed; organizers were blacklisted; and the labor injunction was successfully used.

For their part, southern West Virginia miners had few alternatives to violent confrontation in pursuit of better working conditions. Yet the failure of the strikes to achieve any change in working conditions is not the whole story of their effect on class conflict.

\section{STRIKES AND ACCIDENT LITIGATION: A HYPOTHESIS}

Parallel events suggest that there may have been other, more subtle effects of the miners' collective action. I begin with a finding that emerged as a result of my attempt to examine the validity of alternative theories concerning the role of litigation in stimulating a demand by business for workmen's compensation 
legislation. One theory holds that workmen's compensation was adopted to resolve otherwise uncontrolled problems of class conflict (Weinstein 1967). Another holds that litigation cost owners dearly and thus directly motivated their support for workmen's compensation (Wesser I97I). A third theory, a variant of the last, holds that it was to business's benefit to eliminate the uncertainties of the mature common law of industrial accident liability (Friedman and Ladinsky 1967). In the course of trying to determine the sources and effects of industrial accident litigation in southern West Virginia coal communities, it appeared that accident litigation was at an all-time high precisely at those points at which there were strikes. At other times, the industrial accident litigation rate was lower. The correlation suggested an important, if potentially complex, relationship between collective action and increased utilization of public authority in conflict resolution by individual miners. If such a relationship existed in this instance, the finding would have important implications for the adoption of workmen's compensation. It is possible that accident litigation did cost owners dearly, but what lay behind that cost ultimately was growing class conflict, the mobilization of workers for strikes, and a greater readiness of miners to demand accountability from their employers in court.

The empirical relationship between strikes and litigation is plausible because of an intervening variable: mobilization for collective action. First, we may assume that members of an emerging proletariat choose collective action as a means of confronting the dominant power of owners whenever they can mobilize (Olson 1965). Collective action is simply more effective than individual action (Tilly 1978). Collective resources make possible a variety of strategies for conflict which could not be undertaken by individuals, including hiring attorneys to advise and to litigate. ${ }^{4}$ Further, collective action builds an agenda by giving prominence to practical claims, which lawyers transform into legal language. One possible effect of agenda building is that claims may be asserted more frequently by individuals who are members of an organization which makes the same or other claims against the same parties. Thus, one explanation of the rise in accident litigation by miners against coal companies may be the effects of strike mobilization by the UMWA.

In addition, the legal side effects of strikes might not be limited 
to what miners did. Mobilization for collective action may explain not only litigation and other actions of the protesting underclass but also the changes in the relationship between private power and public authority that occurred as those who experienced the effects of strikes responded. Their responses would in part be demands for further state intervention.

\section{CLASS CONFLICT AND THE MOBILIZATION}

OF LAW IN THE PROGRESSIVE ERA

As illustrated by the alternative explanations of the origins of workmen's compensation legislation, theories of the rise of the modern state in America have attributed the growth of public bureaucracy at the national level to increasing demand for regulation to control the effects of conflict between classes and the effects of competition within the capitalist class. The process of enlargement of the state due to this increasing demand was necessarily complex, in part because the structure through which change could be accomplished, namely the state, was itself the object of change (Skowronek 1982) and in part because the American state structure was highly decentralized and embedded at the local level in "island communities" (Wiebe 1967) with a degree of political autonomy. Wiebe and others have argued that the demand for change was in part an effect of the way in which perceptions, including perceptions of the state, were reconstructed to account for the loss of autonomy experienced by such communities during the rapid emergence of a national economy. These changing perceptions or understandings of the state may be reflected in the state's response to class conflict in industrial settings like Fayette County.

While theories of state transformation in the Progressive Era are helpful in drawing attention to the role of demands made by particular interest groups contending for power, their almost exclusively national focus provides little guidance in understanding how the role of public authority changed in specific communities, in relation to class conflict in particular, or how such changes contributed to the larger transformation. Because the principal theoretical insight of these state transformation theories has been the importance of instrumental responses to interest groups which mobilized the most power, a great deal of research on the Progres- 
sive Era has been focused on determining which groups mobilized to influence the adoption of specific legislation and very little on how conflict, collective action, and the uses of public authority interacted more generally over time. ${ }^{5}$

Understanding the interaction between miners' strikes and the mobilization of state authority requires us to see strikes as more than a localized, industrial equivalent of interest group pressure met by an instrumental response. Steven Lukes (1974) provides a compact framework for describing means of exercising power in terms of three processes: direct coercion of another's actions, control of the process of conflict (i.e., by controlling participation in and the agenda for conflict), and influence over beliefs and values that determine the goals and strategies of conflict. The effects of strikes on the distribution of power were determined, in part through the medium of state authority, by all three of the processes described by Lukes.

Illustrating Lukes's first process, strikes might simply have succeeded or failed instrumentally by forcing an agreement to change work practices or to raise pay or by resulting in no change, loss of jobs, arrests, or other repression. Or, illustrating Lukes's second process, private parties or the state might have controlled the alternatives to strikes-legislative and electoral alternatives or the enforcement of existing laws that might benefit workers-forcing miners to adopt "illegitimate," that is, illegal, means of making demands. Similarly, the strikes might have altered the balance of power by altering the agenda for the use of state power and the future access of workers to state authority, for example, by encouraging legislation to resolve underlying causes of strikes (thus the theory of some Progressive Era historians). Or strikes might have altered the agenda of companies, for example, by encouraging new management practices aimed at reducing strikes-by blacklisting union organizers or by instituting safety measures and cooperative worker-owner management practices.

Finally, strikes might reflect the third process, in that their goals were limited by the belief systems of miners about the importance of particular issues and their capacity to assert them by particular means. We might see this in the priority given to wages, safety, or control of the workplace or in the events that precipitated or ended strikes. Strikes might in turn alter these beliefs. For example, strikes might have helped miners redefine their roles and those of 
operators, enabling miners and operators to see each other in a new light. The strikes might have changed the beliefs of miners about their goals and strategies by making them more aware of the strengths and weaknesses of their position, by increasing the salience of particular issues, or simply by providing a sense of efficacy (or discouragement) in undertaking other kinds of action.

In sum, Lukes's description of the forms of power enables us to see that collective action, even "unsuccessful" collective action (in Lukes's first sense), might have had important effects on the distribution of power. Viewing the interaction of strikes and public authority through Lukes's more comprehensive description of the effects of power sets a much broader agenda for empirical research than a simple model of response to demands in which the chief question is, do miners' wages rise?

Further, Lukes's perspective on power requires recognition of two points that have important implications for the design of research on the relationship between class conflict and legal institutions. First, understanding contention for power requires examination of the interaction of the contenders over sufficiently long periods of time to observe the effects of power holding on the institutionalization of conflict processes. These processes include the establishment of relevant beliefs and values accepted by the contenders. These effects are the result of Lukes's second and third processes. ${ }^{6}$ Thus, an approach which examines the repressive role of the state or the outcome of court or legislative decisions alone may be insufficient to capture the changing agendas of power holders or the impact of power holding on future conflict.

Second, the class nature of the effects of collective action is important and requires a much broader empirical scope than if legal policy alone were the focus. Law compartmentalizes conflict, masking the scope of particular conflicts arising from major underlying social divisions, draining each conflict of the potential support of a wider audience (Mather and Yngvesson I98I), and perhaps denying the legitimacy of the broader conflict altogether. ${ }^{7}$ To learn about this role of law, one must consider as part of a single picture all uses of law in conflicts involving groups of actors defined by such major social divisions, and not consider legal processes involving different areas of doctrine as distinct and unrelated processes. Thus, understanding the role of law in social 
conflict requires examination of the role of law in all social conduct relevant to race relations (cf. Genovese 1974), class relations (cf. Mayhew and Reiss 1969), or gender relations (cf. Mackinnon 1982) or relevant to the maintenance of distinctions between other conflicting groups of actors defined by the social organization of a community, such as "insiders" and "outsiders" (Engel 1984). Patterns in legal process affecting each group may reveal both commonalities in the treatment of particular social interests in many areas of doctrine (Horwitz 1977) and complementary relationships between the effects of different types of legal process or different legal doctrines. ${ }^{8}$ In either case, the results are part of a pattern defined by relations between conflicting community interests and groups of actors and not by legal institutions themselves.

Here I propose to examine only a small part of the terrain on which law played a part in class conflict in southern West Virginia. I will describe how new legal resources were drawn into class conflict in a number of different substantive areas of law. In each case, the action which appears to initiate the process is working-class collective action (i.e., strikes). One of the conclusions I shall draw will be that collective action was by no means the only determinant of the use made of legal resources or of the effects this use had. Though the data are limited, the process linking class conflict and litigation rapidly increases in complexity as I attempt to trace links across different areas of working-class life and to trace the joint effects of these uses of law on class relations.

WHAT THE STRIKES WERE ABOUT:

CLASS RELATIONS AND PUBLIC AUTHORITY

IN FAYETTE COUNTY, I895-I902

Industrialization in Fayette County followed the opening of the Chesapeake and Ohio Railway line along the New River Valley in 1873 . By 1900 , Fayette County was a leading coal-producing county in a leading coal-producing state. By 1900, 27 years after the railroad entered Fayette County and commercial coal production began, the population had increased from 7,600 to 32,000 (Table I). Out of an adult male labor force of 9,207 in 1900, 6,392 were employed as miners. Despite intense industrial activity, the county remained rural. The population of the county 
Table I Industrialization and litigation in Fayette County, I872-I925

\begin{tabular}{|c|c|c|c|c|c|c|c|}
\hline Year & Population $^{\mathrm{a}}$ & $\begin{array}{c}\text { Adult } \\
\text { male } \\
\text { labor } \\
\text { force }^{\mathrm{a}}\end{array}$ & Miners b & Strikes ${ }^{b}$ & $\begin{array}{c}\text { Strike } \\
\text { measure }\end{array}$ & $\begin{array}{c}\text { Criminal } \\
\text { cases }^{c}\end{array}$ & $\begin{array}{c}\text { Miner } \\
\text { eviction } \\
\text { cases }^{c}\end{array}$ \\
\hline 1872 & $7,600^{d}$ & I,335 & $*$ & $*$ & & 37 & 0 \\
\hline I873 & & & $*$ & $*$ & & 26 & 0 \\
\hline I 874 & & & $*$ & $*$ & & $2 \mathrm{I}$ & 0 \\
\hline I 875 & & & $*$ & $*$ & & 23 & 0 \\
\hline 1876 & & & * & $*$ & & I I & 0 \\
\hline I877 & & & $*$ & $*$ & & I I & 0 \\
\hline 1878 & & & $*$ & $*$ & & 29 & 0 \\
\hline I 879 & & & $*$ & $*$ & & I7 & 0 \\
\hline I 880 & I I ,600 & 3,043 & $*$ & $*$ & & 23 & 0 \\
\hline I 88I I & & & $*$ & $*$ & & IO & o \\
\hline I 882 & & & * & * & & 58 & 0 \\
\hline I 883 & & & 3,356 & $*$ & & 38 & o \\
\hline I 884 & & & $*$ & * & & 72 & 0 \\
\hline I 885 & & & $*$ & $*$ & & 84 & 0 \\
\hline I 886 & & & $*$ & $*$ & & 105 & 0 \\
\hline I 887 & & & $*$ & $*$ & & 88 & 0 \\
\hline I 888 & & & 2,309 & $*$ & & I 34 & 0 \\
\hline I 889 & & & $2, \mathrm{I} 66$ & $*$ & & 109 & o \\
\hline I 890 & 20,500 & $5,4 \mathrm{I} 5$ & 2,985 & $*$ & & I 28 & o \\
\hline I 89 I & & & 3,043 & $*$ & & 70 & o \\
\hline I 892 & & & 3,476 & $*$ & & $*$ & o \\
\hline I 893 & & & 3,668 & $*$ & & I 25 & 0 \\
\hline I 894 & & & $*$ & $*$ & & 207 & I \\
\hline I895 & & & 5,120 & $*$ & & 222 & 0 \\
\hline I 896 & & & 9,007 & $*$ & & I 55 & 0 \\
\hline I 897 & & & 5,219 & I ,697 & Miners & I 79 & o \\
\hline I 898 & & & 6,192 & 235 & Miners & I 59 & o \\
\hline I899 & & & 5,929 & 0 & & I 22 & 0 \\
\hline I 900 & 32,000 & 9,207 & 6,392 & 2 & Mines & 98 & o \\
\hline I90I & & & 7,327 & 2 & & 257 & o \\
\hline 1902 & & & 8,089 & 76 & Mines & 329 & 48 \\
\hline 1903 & & & 7,840 & 87 & Mines & 463 & o \\
\hline I904 & & & 8,752 & 3 & Mines & 546 & o \\
\hline I905 & & & 9,687 & I & Mines & 290 & o \\
\hline I906 & & & $9,40 \mathrm{I}$ & I 5 & Mines & 299 & o \\
\hline 1907 & & & 9,346 & 0 & Mines & 278 & 0 \\
\hline I908 & & & IO,4IO & 0 & Mines & 209 & o \\
\hline I909 & & & I0,909 & 22 & Mines & 286 & o \\
\hline
\end{tabular}


Table I-Continued

\begin{tabular}{|c|c|c|c|c|c|c|c|}
\hline Year & Population $^{\mathrm{a}}$ & $\begin{array}{l}\text { Adult } \\
\text { male } \\
\text { labor } \\
\text { force }^{\mathrm{a}}\end{array}$ & Miners ${ }^{b}$ & Strikes $\mathrm{b}$ & $\begin{array}{c}\text { Strike } \\
\text { measure }{ }^{b}\end{array}$ & $\begin{array}{c}\text { Criminal } \\
\text { cases }^{c}\end{array}$ & $\begin{array}{c}\text { Miner } \\
\text { eviction }^{\text {cases }} \\
\end{array}$ \\
\hline I9IO & 52,700 & I 5,628 & I I , I 46 & 6 & Mines & 313 & o \\
\hline I9I I & & & I I ,497 & 2 & Mines & 223 & 0 \\
\hline 1912 & & & I0, I32 & 24 & Mines & 250 & o \\
\hline 1913 & & & 10,536 & I 2 & Mines & 430 & 0 \\
\hline 1914 & & & 10,572 & I & Mines & 385 & 0 \\
\hline 1915 & & & I I, 083 & $*$ & & 712 & 0 \\
\hline 1916 & & & 9,928 & * & & 659 & 0 \\
\hline 1917 & & & 9,732 & * & & 716 & 0 \\
\hline I918 & & & 9,152 & * & & 230 & 7 \\
\hline 1919 & & & 9,402 & $*$ & & $3 I 4$ & 2 \\
\hline 1920 & $6 \mathrm{I}, 500$ & I6,636 & 9,666 & * & & 243 & 20 \\
\hline I92 I & & & I0,888 & $*$ & & 368 & 0 \\
\hline 1922 & & & $9,05^{8}$ & $*$ & & 482 & I5 \\
\hline I 923 & & & 10,485 & * & & 453 & 0 \\
\hline I924 & & & 9,986 & $*$ & & 217 & 0 \\
\hline 1925 & $66,200^{d}$ & & 9,969 & $*$ & & 236 & 202 \\
\hline
\end{tabular}

remained spread relatively evenly throughout the six administrative subdivisions. In I900, the incorporated town of Fayetteville, the county seat, still had only 4I3 inhabitants, while the largest incorporated town, Montgomery, had a population of only I,594 (U.S. Bureau of the Census I90I; West Virginia Department of Mines I90I).

The industrialization of southern West Virginia and the emergence of its proletariat is a story of struggle both to promote and to resist change. Support provided by law for private power was enmeshed in this process. The public policing of this rural county was the responsibility of an elected sheriff, assisted by a few hired deputies and by constables elected for the county and appointed for each magisterial district (the jurisdiction of a justice of the peace). Their numbers remained small throughout the period of 
the study, I872-I925. By I884, the Republican party's grip on Fayette County politics meant that elected county officials owed their offices to the favor of the party of the industrialists (Williams 1976: chap. 4).

Further, coal mining was carried on in relatively isolated locations, typically not in or near the few municipalities. Miners and their families lived in private towns located on the mine owners' property at the site of the mine. Isolation and the consequent lack, for the most part, of any occasion for critical public scrutiny rendered the mine owners immune to social control. The story of company towns has been told many times (Corbin I98I; Eller I982; Thomas I97I; Lane 1924; Athey 1990). West Virginia had a higher proportion of company-owned mining towns than any other state (Corbin I98I: 8). Private order had obvious advantages for coal companies. Among the legal devices used to dominate workers were the employment contract, company-controlled procedures for weighing coal (and crediting miners with pay), payment in scrip, a company store monopoly, and control of company housing. ${ }^{9}$

Although the law governing the power of the owners of company towns might have been invoked at any time, it seldom was, either by owners legitimating that power or by miners challenging it. Private dominance included the threat of firing and removal from company housing and the threat of physical brutality. Other barriers to seeking relief from public authority included the cost of litigation and the dependence of many local attorneys on business brought by coal companies, though later events demonstrated the availability of at least a few attorneys willing to take miners' cases to court. ${ }^{10}$ Less easy to measure, some barriers to invoking public authority were created by the beliefs of miners themselves about the claims that could be made. There is an important difference between the cotters and peat gatherers of Whigs and Hunters and the emerging industrial proletariat of England and America. A newly formed industrial proletariat must formulate claims appropriate to new circumstances (Thompson 1975). Peasants and artisans protecting traditional and customary privileges had "rights" to focus both individual and collective resistance. An early industrial worker in America had a customary and contractual right to a wage and little else. A question that must be asked with respect to the striking miners of Fayette is whether their consciousness of entitlement included compensa- 
tion for accidents, what knowledge or other factors were likely to have affected miners' perceptions and willingness to act on them, and whether the existence or importance of an entitlement was affected by mobilizing for strikes.

The introduction of new legal rights affecting the relationship between miner and mine owner, and new interpretations or patterns of enforcement of existing legal rights, indicated the changing role of public authority. In the West Virginia state legislature and in the control of statewide offices, industrialists ruled; by 1900 the party label was almost immaterial (Williams 1976). Yet examination of the statutory law reveals the adoption of rudimentary safety laws, addressing primarily problems of ventilation, drainage, and adequate timbering, and the creation of a state system of mine inspection as early as I883. ${ }^{11}$ In I 887 the state legislature enacted antiscrip and anti-company store laws and in I89I added provisions requiring state-inspected scales for weighing miners' daily production of coal and a miner-chosen check weighman. ${ }^{12}$ Perhaps more remarkable still, the West Virginia Court of Appeals eventually upheld these latter laws against substantive due-process challenges that had been the basis for holding similar statutes in many other states unconstitutional. ${ }^{13}$ This is evidence that the power of industrialists at the state level was not unchallenged. Both organized labor in the northern part of the state and elites not wholly sympathetic to industrial interests continued to have some power in state government.

Industrialists remained firmly opposed to safety and inspection laws, except to the token extent required to maintain their legislative hegemony. As a practical matter, this meant that they were able to keep the penalties small and the number of mine inspectors inadequate for the task. Moreover, the chief inspector was invariably an operator or someone sympathetic to the operators. The statutes were filled with loopholes and yet were seldom litigated at the appellate level (Massey 1970). Further, between I890 and I9IO only a handful of indictments were sought against coal companies under these laws in the Fayette County Circuit Court. ${ }^{14}$ The absence of litigation at both levels hardly seems consistent with an aggressive program of enforcement. Can we conclude that the effects of regulation by the state of West Virginia prior to I9IO were insignificant in the relationship between miners and owners in Fayette County?

The creation of new rights articulated by law suggests that the 
miners' understanding of their relationship to owners and to public authority changed. Miners testified before Congress to the widespread violation of these laws. The testimony shows that at least some miners knew that the laws existed. Moreover, courts existed to enforce the new rights. Williams (1976) describes lingering resistance at the county level to industrialists and attachment to traditional political loyalties. By the early twentieth century, local coal barons were said to dominate Fayette County politics. But in one sense, West Virginia was one of Robert Wiebe's ( 1967) "island communities," unprepared for the industrialization which engulfed it. On one hand, local public authority, the courts in particular, provided a legitimate means of protecting the rights of private property, on which industrialization and dominance depended. On the other, the local courts, which provided much of the administrative structure for the county, could not remain closed to conflicting values, both those internal to legal traditions and those expressed by the behavior of juries and litigants themselves.

The enforcement of the laws regulating the working conditions of miners illustrates the problem of miners' "rights." Mining inspectors could swear out an information (or complaint) charging violations of the laws governing safety, fair wage payment practices, or check weighmen, but the only significant threat to operators who were violating the law were complaints by miners themselves, since the number of inspectors remained less than half a dozen in 1900. Thirty misdemeanor informations were sworn out by Fayette County miners during the first three years following the establishment of an active program of inspection in I888. Upon each of these the grand jury returned an indictment at the request of $\mathrm{C}$. W. Dillon, the county prosecutor, and operators were fined a nominal amount under the statute. ${ }^{15}$ Twenty-five of the complaints were against one employer. This suggests that at first there was no lack of willingness by the public prosecutor or the grand jury to act on complaints by miners. Between I89I and 1895,15 complaints were made by miners, and these led to indictments. Between I896 and 1900, the number of complaints declined to I3. Between I9OI and I905 the number declined to 3, and between 1906 and I9IO it was again 3. The pattern suggests declining willingness by miners to complain about company practices. In view of the minimal sanctions attached, employers had 
little incentive to reform. In view of the ready means of retaliation available to operators, miners had little incentive to continue to complain. Further, after 1890 , new labor from outside the state and from abroad flooded the coal camps. The precariousness of the miners' position increased.

We cannot conclude that claims to safety, an end to unscrupulous wage payment practices, and autonomy (i.e., freedom from the domination of the company store), which the statutes embodied, were not valued by miners. Significantly, it was in part for fair wage payment practices and an end to company stores that the Fayette County miners struck in waves between I 895 and 1903. The strikes promised an alternative means of winning the same rights that state regulation had failed to secure. Thus, the effects of early state regulatory reforms are ambiguous. While state statutes may have in some way legitimated these claims, the enforcement mechanisms provided by public authorities appeared to offer little to the miners.

\section{COLLECTIVE ACTION AND LEGAL DISCIPLINE}

How did mobilization of public authority, and specifically legal process, change as a result of strikes? In this section I will discuss changes in the uses of public authority that tended to maintain the existing private order, the public order, the order of workeremployer relations, and the order of the market. Using sketchy data available through court records, I will illustrate each of these points by examining the apparent effects of strikes on litigation of three types: criminal prosecutions, housing evictions, and debt and receivership proceedings against coal companies.

\section{Criminal Prosecutions}

While criminal law supported private power in many obvious ways, in the coal camps order was kept by means condoned but not established by public authority. The capacity of the regular public police at all times during the period under study was quite limited. Company towns were policed by special deputies who were paid for by the mine owner and whose duties were limited to those assigned them by their employer. Their number fluctuated, depending on the owners' concern about order, and 
appears to have been regularly increased during strikes (Lane I924: 20). Among other duties, special deputies were often employed to intimidate union organizers and to do the dirty work of strikebreaking.

Since the special deputies of the coal towns were unlikely to be concerned about more than the immediate resolution of disturbances or enforcing compliance with company policy, their activity bore little relationship to the requirements or formalities of the legal system and would have had little impact on the routine criminal prosecutions in the courts. If this is so, much of the social control manifested in keeping order among the members of the rapidly increasing working class of the county would not be reflected in the criminal prosecutions of the county. Examination of the criminal court records of Fayette County shows that the increase in criminal cases after I 873 closely followed the increase in population until about I885. After I 885 much of the increase in population must have taken place in company towns (in which, Corbin [198I] estimates, almost $98 \%$ of the southern West Virginia miners and their families lived), and after this date the number of criminal cases rose more slowly than the population. Indeed, from I89I until the beginning of World War I the fluctuation in the number of criminal cases appears to bear no relationship to the increase in population at all..$^{16}$

Industrialization of the county is reflected in fluctuations in the number of criminal cases during strikes. A rise in the number of criminal cases is apparent during strikes (I895, I898, I902-3). This rise was due, no doubt, to increased violence, but it also reflects the increased capacity for policing which local and state governments mustered during strikes by calling in state militiamen, obtaining the assistance of federal marshalls, or hiring additional deputies.

The massive strikes called by the United Mine Workers of America in 1902 and 1903 provide an example of the link between criminal law enforcement and strikes. In addition to an increase in the number of mine guards, the governor, at the request of the sheriff of Fayette County, authorized protection of the mines, by militiamen under the command of William N. Page, the spokesman for the coal owners (Harris I969: 238). During these two years, criminal prosecutions increased by $66 \%$, reaching their highest level prior to I9I5. Similarly, there were noticeable, though smaller, increases during other strikes. 
Why did prosecutions increase along with the use of force to protect the mines? Why was the legitimating effect of a public prosecution required in these periods but often not for the handling of more routine crimes in the coal camps? Presumably, the answer lies in part in the simple fact that at such times the actions of coal mine owners and their special deputies were open to greater public scrutiny. But prosecutions and criminal sanctions were made necessary when the threats and rough handling of individual miners by mine guards were no longer sufficient to prevent resistance to owner domination.

\section{Housing Evictions}

Critical not only to the maintenance of control in the coal camps but to the prevention of any form of collective activity by miners was the power companies exercised over housing. The Coal Commission appointed by the United States Senate in I92 I to investigate conditions in the coal fields was provided with examples of written leases used by mine owners in Pennsylvania and other states to restrict access to the company towns and to control the behavior of miners. It heard testimony that West Virginia mine owners engaged in similar practices. Judicial support was, of course, critical, although few miners were likely to challenge leases or evictions in court, because of the cost, because of the power of owners to blacklist or bring other, more immediate sanctions to bear, and possibly because attorneys would find such clients and such suits unattractive. But if one miner succeeded in resisting eviction or having a lease declared void, the owners had much to lose. Witnesses before the commission claimed that the West Virginia circuit courts held that miners' leases were controlled by the law of master and servant, so that the lease ended automatically when the job ended, notwithstanding West Virginia law that governed other landlord and tenant relations to the contrary. ${ }^{17}$

Even circuit court cases of this type were rare. Significantly, in view of all the barriers to bringing them, they were brought to the circuit court in quantity during years of major union-organizing drives. The cases which appeared on the circuit court docket in I903 were brought by the companies before a justice of the peace under the West Virginia law which allowed eviction upon termination of a lease. The fact that the mine owners did not follow 
the usual practice of dumping the miners' belongings in the road suggests one effect of collective support for the assertion of legal rights and explains why the mine owners required the support of public authority under these particular circumstances. Not only were owners forced by the miners to employ the courts, but in the jury trials held before a justice of the peace the miners won verdicts allowing them to remain in their houses. The cases were quickly appealed to the circuit court, where the miners' attorney, evidently knowing the court's lack of sympathy, settled all the cases (Thomas I97I). ${ }^{18}$

\section{Debt and Receivership}

Miners' strikes had ripple effects which were magnified by legal relations. Business failures followed in the wake of strikes that interfered substantially with production. For example, strikes contributed to an attrition rate of over $35 \%$ among coal companies between I895 and 1900 and an attrition rate exceeding $26 \%$ between I90I and I905. Thereafter, the attrition rate steadily declined until after World War I. Many failures can be traced in the litigation histories of individual coal-mining operations. In the litigation histories of small mining operations, debt and contract cases cluster in poststrike periods, just before dissolution or buyout (Munger $1987 \mathrm{~b}$ ).

\section{COLLECTIVE ACTION AND CHANGES IN LITIGATION}

The strike years 1902 and 1903 witnessed the filing of a record number of cases in Fayette County Circuit Court for compensation for mining injuries. The rise in the number of cases reflects not only an increase in the number of accidents (see Table 2) but an increase in the rate at which mine accidents resulted in litigation. Moreover, the coincidence extends to other periods of strike mobilization. Of the four five-year periods presented in Table 2, the two in which the most militant collective action by miners took place, specifically in 1895 and $1902-3$, also witnessed the highest accident litigation rates. ${ }^{19}$ Nor does any change in the law explain this rise in litigation (see Munger 1987a). The coincidence of strike mobilization and accident cases heard in court must be explained by some other change which influenced the process of 
Table 2 Mining accidents and litigation rates, Fayette County, I887-19I5

\begin{tabular}{|c|c|c|c|}
\hline Year & Number of accidents & Number of court cases & Litigation rate \\
\hline I887 & 20 & o) & \\
\hline I 888 & $23^{\mathrm{a}}$ & 2( & \\
\hline I 889 & 25 & $2\}$ & .04 \\
\hline I 890 & $3 \mathrm{I}$ & o) & \\
\hline I89I & I9 & I & \\
\hline I892 & 35 & 2 & \\
\hline I893 & $4 \mathrm{I}$ & 5 & .10 \\
\hline I 894 & $36^{a}$ & 7 & \\
\hline I 895 & $3^{6^{a}}$ & 2 & \\
\hline I 896 & 33 & 4 & \\
\hline I897 & $5 \mathrm{I}$ & I & \\
\hline I 898 & 43 & o & .03 \\
\hline I 899 & 57 & I & \\
\hline 1900 & 102 & 2 & \\
\hline I90 I & 72 & $9 \mid$ & \\
\hline 1902 & 73 & 0 & \\
\hline 1903 & 72 & I6 & .07 \\
\hline I904 & 77 & 3 & \\
\hline 1905 & I 28 & 31 & \\
\hline 1906 & I35 & I) & \\
\hline 1907 & I64 & I & \\
\hline 1908 & 238 & $4\}$ & .05 \\
\hline 1909 & 276 & 6 & \\
\hline I9IO & 279 & 421 & \\
\hline I9I I & 215 & 2 & \\
\hline 1912 & 190 & I & \\
\hline 1913 & I 57 & $16\}$ & .02 \\
\hline 1914 & I 44 & 5 & \\
\hline 1915 & 533 & I & \\
\hline
\end{tabular}

${ }^{\text {a Estimated. }}$

bringing accident cases to court, either a change which altered the willingness of miners to sue or a change which increased the receptiveness of attorneys or other key figures to the idea of bringing cases by miners to court.

One possible explanation is that union organizing may have 
crystallized miners' beliefs in the value of legal claims or, more likely, that it may have increased the sense of efficacy of individual claimants, who pursued legal remedies beyond the point at which they might otherwise have been dissuaded by an attorney. But further examination is revealing. It is particularly difficult to determine whether miners' consciousness of legal rights or the value they placed on them increased. Indirect indicators of their views suggest not. Striking unionized miners in Fayette County did not demand greater safety in 1902-3. They demanded economic autonomy, in the sense that their main concerns were the company store, scrip, and corruption in the weighing of coal (Thomas I97I: 257). Safety, as a collective demand, was undermined, if not foreclosed, by the greater wages which could be earned from unsafe mining practices. Failure to demand safer mining conditions is explained not only by miners' economic selfinterest but also by the belief that deaths and injuries to miners arose in the first instance from the carelessness of other miners. Thus, blaming careless miners was an alternative to confronting the company. ${ }^{20}$ Not coincidentally, this belief also reflected the values underlying the "fellow servant" and "assumption of the risk" doctrines, which made recovery for industrial accidents difficult under the common law. The UMWA's first safety demands were for miner certification, not mine inspection. ${ }^{21}$

If there was no change in the willingness of miners to sue, more subtle effects of class conflict may have contributed to other changes which affected miners' access to courts. First, an important link between resistance to eviction and accident litigation was forged by the legal profession. If the hostility of the circuit court to eviction defense was manifest, and if there was no accepted basis in law for defending the claims, it would take an identified "plaintiffs' lawyer" to defend the miners, an attorney who was willing to risk the irritation of local judges and the hostility of mine owners to serve the interests of clients opposing the coal companies, and one who found a means of making a living doing so. Indeed, there is evidence that specialization by type of client was occurring. An examination of the names of individual lawyers and law firms who represented coal companies and parties opposing coal companies between I880 and 1925 shows that more attorneys represented both coal companies and litigants against them prior to 1900 than after. Thus, if before 1900 attor- 
neys in Fayette tended to represent both operators and miners in their practices, attorneys after 1900 moved toward partisanship. Some represented operators, a wealthy class of clients, and as a consequence represented few miners. Representation of miners in actions against operators became increasingly concentrated in the practice of a single law firm which was relatively independent of business clients and which represented few operators. Over $40 \%$ of miners' accident cases brought between 1890 and I9I0, primarily after 1900 , were brought by $\mathrm{C}$. W. Osenton or members of his firm..$^{22}$

The concentration of representation of miners in this law firm may be explained in part by Osenton's prior specialization in criminal law. C. W. Osenton's frequent contact with working-class criminal defendants, as much as his relative financial independence from clients who employed the miners, may explain the disproportion of employee injury cases in his practice. ${ }^{23}$ Collective action by miners may also have helped Osenton's firm establish a stronger bond with working-class clients. Osenton represented striking miners resisting eviction from company housing in 1903 , and it is plausible to infer that his representation of striking miners flowed from his frequent contact with miners in other types of cases. Notwithstanding the concentration of cases in Osenton's firm, many other attorneys also continued to represent miners in accident litigation throughout the period, though they handled only one or two cases each. Yet, for representation in cases in which the issues in litigation were more explicitly related to class conflict, as in strike-related eviction cases, the miners chose attorneys who were more closely identified with them by the nature of the attorneys' principal client base.

Second, juries' sympathies changed, yielding an increasing proportion of miner victories at trial, just when the litigation rate increased (Table 3) ${ }^{24}$ Increasingly favorable results for miners at the circuit court level appear to be correlated with mine disasters, not with any change in the law. The number of mine disasters increased in the early twentieth century. Some of the most spectacular occurred in West Virginia, and Fayette County experienced its share. ${ }^{25}$ Further, the proportion of cases brought to court which arose out of fatalities went up, indicating more careful selection by an increasingly specialized bar and suggesting another possible explanation for the change in the sympathies of 
Table 3 Outcomes of tort cases against coal companies, Fayette County, I890-1910

\begin{tabular}{|c|c|c|c|c|}
\hline Outcome & $\begin{array}{c}\text { I89I-95 } \\
(\%)\end{array}$ & $\begin{array}{c}\text { I896-I900 } \\
(\%)\end{array}$ & $\begin{array}{c}190 I-5 \\
(\%)\end{array}$ & $\begin{array}{c}1906-10 \\
(\%) \\
\end{array}$ \\
\hline $\begin{array}{l}\text { Won by plaintiff } \\
\text { (Jury trials only) }\end{array}$ & $\begin{array}{c}6.7 \\
(\mathrm{I} 6.7)\end{array}$ & $\begin{array}{c}0 \\
(0)\end{array}$ & $\begin{array}{c}2.9 \\
(20.0)\end{array}$ & $\begin{array}{c}15.6 \\
(58.8)\end{array}$ \\
\hline Won by defendant & $33 \cdot 3$ & $37 \cdot 5$ & I I .8 & IO.9 \\
\hline Settled & 40.0 & 62.5 & 76.5 & 71.9 \\
\hline Arbitrated & 0 & 0 & 0 & 0 \\
\hline Removed to federal court & I3.3 & 0 & o & I6 \\
\hline Total & IOO & IOO & IOO & 100 \\
\hline Cases $(N)$ & I 5 & 8 & 34 & 64 \\
\hline Appeals $(N)$ & o & o & o & 3 \\
\hline
\end{tabular}

juries and judges. As deaths rose, attorneys focused on litigating those cases rather than on ones involving nonfatal injuries. So, while increasing rates of litigation appear to have corresponded to strikes, increasingly favorable judgments appear to have resulted from increasing numbers of deaths, in particular the shock of mine disasters.

The increasing numbers of deaths, one might speculate, were an inevitable result of competitive forces driving new technologies, primarily new machinery that produced coal dust and the introduction of electricity, which provided a source of ignition for explosions. The explosions in the New River and nearby coal fields occurred, moreover, during the period in which the Chesapeake and Ohio Railway, which served the coal fields, was owned by the "community of interest," a railroad oligopoly controlled by eastern financiers (Williams 1976). As a result of reduced competition, the railroad was able to raise shipping rates, squeezing operators' profits and driving production in these coal fields to new heights (Williams 1976: 154-55, 159).

Litigation between miners and mine owners may have increased in part due to miner mobilization, but the most persuasive link is an indirect one: the recruitment of attorneys who continued to specialize in working-class litigation. The effects of unioniza- 
tion and strikes on individual miner's decisions to pursue accident litigation are less certain. The ingrained sense that courts were alien, the lack of direct union support for aggressive litigation on this issue, and the class differences between attorneys and miners all may have left individual miners and their families in the grip of their own strong sense of the limitations of litigation as a resource in conflict. Essentially it fell to attorneys to encourage or discourage litigation.

COLLECTIVE ACTION AND SOCIAL

AND LEGISLATIVE CHANGE

\section{Tort Law Reform}

Having explored the sources of industrial accident litigation, I turn to an examination of its effects. To what extent did the particular combination of collective action, changing organization of the legal profession, changing organization of production, and (as another mediating variable) public sympathy drive operators to support legislative intervention? Later, I ask, more generally, to what extent class conflict or the changing organization of the economy systematically altered the reliance of working class and operator class on public authority (invoking the conceptual scheme I began with). The answer to the former question was no easier to pursue than the answer to the question of the link between law and working-class collective action. In the case of the operators, however, I can at least surmise the direct impact of the litigation. I estimated the value of an average case brought by a miner (or his estate) against an operator. Based on the highest litigation rate during the period I studied and the lowest return per ton of coal, operators paid at most between $3 \%$ and $5 \%$ of gross revenues to miners as a result of litigation. Since much of this litigation failed or was settled, and because gross revenues were higher and litigation rates lower for much of the period, the actual legal liability was considerably lower. Further, litigation was, in the main, predictable because of the mediating role of attorneys. Over $60 \%$ of the cases were settled. Thus, operators could count this as a small but necessary and routine cost of doing business.

Of course, the burdens of litigation were not equally distributed among operators. Small operators probably faced more litigation 
per ton and had less leverage to dissuade litigants. At the same time, their interests counted for less in the political battles over the creation of the regulatory state during the Progressive Era. Big operators should have easily weathered accident litigation.

One potentially significant factor whose effect on mine owners' support for legal change I cannot estimate was the unpredictable mine disaster. It seems quite plausible to me that the open-ended risk of a costly disaster would provide considerable motivation for the kind of disaster insurance and public relations gain acquired through regulation. So, in the end, a combination of market forces (which made individual operator-financed solutions difficult and encouraged breakneck production) and political forces (including public perception of the most visible carnage) played an important role in the turn to regulation.

\section{Changes in Class Relations}

Notwithstanding the favorable jury verdicts obtained by miners resisting eviction, ownership of company housing continued to be a powerful weapon against strikers and troublemakers. As the court records show, this grip could be resisted but not broken by invoking public authority in 1902 and 1903 . But the resistance counted. It must have made owners consider the future.

Shortly after the strikes of 1902-3 ended there was a wave of municipal incorporations among the coal towns of Fayette County. It is interesting to speculate on the motivations of the mine owners. The working-class population had grown beyond the capacity of any private organization to control it. Police and courts were needed in critical periods of conflict. Municipal incorporation meant a more subtle form of social control: amenities, such as parks, sewers, and commerce. There are no studies of the development of these coal camps as municipalities. The actual adjustments were likely to have been modest.

Empirically, the link between collective action and effective resistance to domination by other means was complex. As examination of eviction and accident litigation has suggested, claims must be defined before public authority can be invoked. Workingclass culture and the limited range of practical alternatives may have worked against miners in framing a claim for greater safety and for more effective compensation for injury. In addition to the 
problem of claim definition, there were many intervening factors, not the least of which was local attorneys. The success of litigation increased, in part because of changes in the organization of the legal profession and in part because of the impact of mine disasters on juries and judges. This success may have been anticipated by attorneys, explaining, in part, the rising rate of litigation. The relationship between collective action and accident litigation remains an interesting question.

The simultaneous increase in favorable trial outcomes suggests that juries, judges, or both were favorably disposed toward miners' accident claims in spite of the barriers to recovery which legal doctrine continued to impose. This change in point of view in turn implies that other factors were at work. Local social conflict involved political control or more subtle local changes in class or culture, and broader currents encompassed West Virginia as well as other parts of the country. While many of these currents worked on owner behavior in other ways, it is apparent that the pressures of litigation could be an important mediating process beyond the control of owners.

\section{CONCLUSION}

Law may influence actors' choices among the alternatives available for creating or resolving conflict by making public authority available on certain terms. Strikes, in combination with the changing organization of production, altered both the process of choosing among alternatives (some of which were provided by law) and the choices available through law. Strikes influenced the patterns of litigation, attorney availability and specialization, jury decisions, business failures, policing, legislative reform, and possibly even the structure of local government. These changes are part of a pattern of conflict between broader community interests and part of a continuously changing pattern in which the interests of industrialists remained dominant. While different patterns are apparent with respect to different legal conflicts between miners and operators, viewed together, these patterns of legal involvement in conflict help us understand the maintenance of class dominance in the economic and political life of West Virginia communities at the turn of the century. 


\section{NOTES}

I These illustrations were drawn from a larger study of litigation and social change between 1872 and 1945 in Fayette, Raleigh, and Summers counties. A large database was created containing information about some 36,000 cases heard by the state circuit courts in the three counties over the period (see Munger 1988). Historical research on the communities and on particular groups such as miners and coal mine operators has provided a detailed context for examining particular patterns of litigation. In this article I select a few of these patterns for closer consideration. In a previous article (Munger 1987a) I examined patterns of tort litigation and pursued the hypothesis that increases in accident litigation motivated demands for workmen's compensation laws. The results of my prior research form part of the background for the present article.

2 The pattern of class conflict leading to violence in labor struggles was repeated in West Virginia's later labor history and in the labor history of other industrializing communities. In this context, the abject failure of the strike from the miners' point of view was particularly ironic, since there was a direct link to a strike by Pennsylvania anthracite miners, whose success and indirect support from the federal government appear to mark a major turning point in the slow shift of support by national public authorities for labor (Thomas 1971: 255-56). This shift, however, was far removed from the experience of the southern West Virginia coal fields.

3 The Raleigh County grand jury later refused to indict Laing for murder (Thomas 197I: 26I).

4 The capacity to hire an attorney implies that a group has mobilized for more than transient protest. Striking UMWA miners, and organized workers generally, possessed this capacity and made frequent use of attorneys to defend them in legal actions taken against strikes and strikers. I discuss the role played by attorneys later in the essay. In the long run, the usefulness of legal representation was related to miners' success in organizing. In Fayette County, where organizing was unsuccessful, relations with attorneys were episodic and defensive rather than proactive and part of a forward-looking strategy. Failing to establish a more institutionalized role in the labor process, unions themselves seemed to fail and failed to make any use of the law in conflicts with employers. Elsewhere I explore the consequences of the weaknesses of Fayette labor organizing and the absence of a continuing relationship with attorneys. (Munger forthcoming).

5 From a national perspective, much research has considered political party realignment, activism by the leaders of specific interest groups, and, to a lesser extent, working-class protest (see generally Graebner 1976: chap. 5). Different writers have emphasized the importance of different constituencies; for example, in discussions of the adoption of workmen's compensation, Weinstein (1967) and Lubove (1967) attribute a determinative role to the National Civic Association and other leading business interests, Wesser (1971) to social reformers, and Friedman and Ladinsky (1967) to broader changes in public opinion and "culture." More recently, Skowronek (1982) has added to the complexity of this picture by appending to the list of 
interest groups the internal constituencies of existing legal, political, and bureaucratic institutions, whose resistance delayed the establishment of means of regulatory intervention by the state in spite of the demands of powerful economic interests.

6 Contemporary dispute-processing theory seems ill equipped to help us understand the dynamic qualities of the relationship between contention for power and law. A widely employed paradigm classifies litigants as haves or have-nots and argues that the former are advantaged in all phases of mobilization of law and litigation, and that this advantage leads to their coming out ahead in long-run interactions between law and change (Galanter I974). The argument, however, divorces the characteristics which actors have as litigants from interests which they have as members of a community or society. Because the have/have-not characterization misses the actors' own interests, it is not a good guide to the impact of litigation on change. What is a success? The classification reduces success or failure to legal outcomes without comparing outcomes with the actors' own needs or dependence upon legal resources. One might cite the example of a firm near bankruptcy - capable of defeating any one creditor but failing because of its inability to avoid a multiplicity of suits. The company is doing infinitely worse, measured by its own survival capacity, than the individual defeated creditors. Similarly, the impact of litigation on coal operators was entirely relative to their economic circumstances, in turn dependent on a highly competitive market. The have/have-not paradigm misses altogether the true meaning of "coming out ahead" under these circumstances. Another way of making the same point might be to say that "true" haves do not litigate at all. Powerful actors can choose to litigate or to pursue or control conflict by other means. Thus, avoidance of litigation may indicate greater success than winning at litigation. The pattern is further confused, of course, by the fact that avoidance of litigation also may be evidence of still other circumstances, for example, not having the resources to litigate or normative ordering, which deflects conflict away from litigation and toward other forms of dispute resolution (Engel I984).

7 One of the reasons that dispute-processing theory has overfocused on litigation and failed to examine actors as nonlitigants is that dispute processing often uses the legal definition of issues to define conflict. Social change and class conflict refer to social process involving broad classes of actors. Some arenas of conflict are captured by legal issues, but many others are not (Kidder I980-8I). My focus has been on a historically specific class of actors.

8 Bilateral conflict which results in little third-party intervention has been scrutinized by students of dispute processing and litigation. The limits of prior conceptualizations of bilateral conflict are revealed in the conclusion that avoidance of litigation is characteristic of "continuing relations" between parties because such relations are mutually beneficial, and that parties will settle differences in a manner that allows mutual benefits to continue rather than seek resolution by a third party (Macaulay I963, I977, 1985; Lempert and Sanders 1986). This characterization of continuing relationships is greatly oversimplified (see also Yngvesson 1985). Many 
continuing relationships are of a different character altogether because they are based on unequal or unilateral control of the terms of the relationship, for example, the relation between a king and his subjects (bargaining by riot may be a routine form of dispute resolution [Rude I97I]), or the relationships between auto companies and their new-car dealer franchisees (Macaulay 1966), or the continuing class relations between miners and coal mine operators. Within each of these continuing relationships actors may attempt to gain longer-run benefits. This involves a degree of consent to the constraints which one actor (even in the "mutual interest" situation) may place on another actor. For example, miners may "agree" to work in unsafe conditions to obtain the highest possible wages in the belief that no alternative way of earning satisfactory wages exists (cf. Cohen and Rogers I983: chap. 3).

9 I have omitted many other obvious sources of public support for corporations, such as property laws, tax laws, laws governing incorporation, and laws governing liability to other property owners (see Horwitz 1977). Further, there were basic conditions of governance that affected both owners and miners. Finally, miners may have been affected by early social welfare statutes and other laws that I have not considered.

Io I have recently completed a study of the law practices of Fayette County attorneys (Munger forthcoming). Attorneys, even those who received substantial business from coal companies, were willing to handle employee accident litigation until a more specialized group of attorneys emerged about 1900. But some matters involving class conflict more closely and directly were handled by a very small number of attorneys. The story of the arrival of one of them and the role he played is told below.

I I 1883 West Virginia Acts, Chapter 70.

I2 I887 West Virginia Acts, Chapter 63; I89I West Virginia Acts, Chapters 76 and 82 . As I explain below, the enactment of these laws reflects the importance of anti-industrial elite factions in West Virginia politics, in particular legislators from agrarian, anti-industrial areas who sponsored prolabor legislation. Two of them, attorneys James H. Ferguson and C. C. Watts, weave their way into the Fayette County narrative by virtue of Charleston-based law practices that brought them occasionally to Fayette. In I89I, Ferguson sponsored the legislation outlawing scrip and requiring a check weighman.

I3 In I889 the West Virginia Court of Appeals had struck down I887 antiscrip and anti-company store legislation that applied to the mining industry alone. State v. Goodwill, 33 W.V. I79 (1889); State v. Fire Creek Coal and Coke Co., 33 W.V. I88 (I889). Three years later, with a member of the Granger legislative faction that sponsored the prolabor legislation sitting as chief justice, the court upheld general antiscrip legislation and a check weighman statute enacted in I89I. State v. Peel Splint Coal Company, 37 W.V. 802 ( 1892 ).

I4 Resistance to enforcement at the county level in coal-mining areas is further reflected in continuing entertainment of constitutional challenges to the statutes by county criminal courts even after the ruling by the state 
supreme court in the Peel Splint case (see note 13) upholding the statutes' constitutionality (Charleston Gazette 30 Oct. I895).

15 Prior to the 1870 , Fayette had few resident attorneys, especially if we discount two early arrivals who seem not to have established substantial practices. C. W. Dillon was a "second-generation" Fayette attorney in the sense that he read law in the office of one of the first resident attorneys, J. W. St. Clair. St. Clair's practice included not only the new industrial interests in the county but also cases brought by miners. Dillon, a Republican, assumed the mantle of leading practitioner, and his partnership became increasingly probusiness.

I6 A scatterplot of crimes against population shows the incidence of crime increasing steadily until the mid-I 890 S. From I 890 to I 925 crimes increased at a much slower rate than population, but with enormous variations, including extremely high rates of prosecution during the strike years 1902 and 1903. Regression analysis confirms this relationship. The coefficient of population in a regression of crimes on population, controlling for fluctuations in crimes due to changing prices, is highly significant for the period I872 to I9I4 ( $p<$.00I), less significant for the period I889 to I9I4 ( $p<$ .02 ), and not significant for the period I900 to I9I4. The decreasing statistical significance does not seem to be an artifact of the smaller numbers of cases in regressions 2 and 3, since the coefficient of population becomes much smaller and eventually changes sign for the last regression.

I7 The testimony, if accurate in detail, implies that the leases were oral rather than written, and that the courts found a condition subsequent by implication of law rather than by express condition of the contract. I have been unable to find a single West Virginia Court of Appeals case on this point, and the commission's witness may well have been referring to rulings by circuit court judges in cases that were never appealed.

I 8 The miners' attorneys on these occasions were not anonymous members of the bar. Early eviction cases ( I885) were settled by attorneys from Charleston who were part of the Ferguson-Watts network of Democratic party dissidents among the West Virginia elite (see note I2). During the 1902 strikes, the attorney representing the miners was C. W. Osenton, who had just established his practice in Fayetteville and soon established the second most substantial partnership in the county, after Dillon's. As I discuss more fully below, Osenton had an important role to play in bringing miners' accident litigation to court. Osenton's career and practice contrasted in many ways with Dillon's. Dillon was locally trained, a Republican, established an enduring partnership with E. L. Nuckolls, and was, by actual count of cases, firmly on the side of business. Osenton was law school-trained (Georgetown), a Democrat (with all that that implied), and briefly a partner of C. C. Watts, a criminal lawyer, and had a partnership that was continually reconfigured by the departure of attorneys who moved to other cities, entered political office, or died. Most significantly, possibly, was Osenton's access to working-class people and their familiarity with him as a result of his criminal law practice. However, Osenton was by no means a labor attorney. That role was left to others with stronger ideological leanings and with 
the continuing support of the labor unions in the state. What we see in the differences between Dillon's and Osenton's law practices is the evolution of law firm practice in a small town where the nature of practice and the law firm structures have become adapted to particular client bases. Osenton was no more a maverick than Dillon and never became an advocate for miners' causes as his Charleston-based colleagues did (see Munger forthcoming).

I9 A detailed analysis of the causes of this increase appears elsewhere (see especially Figure 4 and the accompanying text in Munger 1987a). The analysis shows that neither increases in the numbers of miners nor increases in coal production fully explain the rise in accident litigation. Notwithstanding these findings, tracing the connections to other causes, including miners' rights consciousness, is a difficult process and must be based on inferences from sketchy data, a shortcoming that will be apparent as the argument proceeds from this point.

20 Thus, Wallace ( 1987 ) describes safety legislation proposed by Pennsylvania anthracite miners in 1868 that required stricter supervision of miners rather than higher standards of mine construction or maintenance. Graebner ( 1976 ) also reports that in the Progressive Era safety took a back seat to job security prior to union recognition, evidenced typically by sharp increases in safety-related grievances after union recognition. Asher (1986) argues, to the contrary, that American workers in the late nineteenth century were conscious of risks and frequently took action to achieve greater safety. Citing specific instances to support this conclusion, Asher also claims that the conclusion of other scholars that relatively little attention was paid to the employer's responsibility for risks is based in part on faulty federal labor statistics that underreport the incidence of safety as a motive for concerted action. However, neither my own conclusions nor the accounts of Wallace and Graebner rely on such statistics.

2I The law and the UMWA's miner certification strategy tended to exacerbate deep divisions already present among miners. West Virginia's miners were native Appalachians, blacks from the Deep South, English miners, and southern and southeastern Europeans recruited by an aggressive West Virginia Department of Labor. The division of the living quarters of coal camps by ethnic group reflected the persistence of national and racial divisions after relocation to West Virginia. Further, strike mobilization was also divided along ethnic lines. Fayette County strikes in I895 were led by militant black miners. Only half-heartedly supported by white miners in this strike, blacks withdrew from subsequent UMWA struggles in the region (Thomas I97I: 248). Subsequently, blacks and foreign laborers were used as strikebreakers, adding fuel to already tense interethnic relations. Finally, the common law, by excusing an employer from liability for an injury to a worker attributable to the negligence of a fellow worker, invited ethnic prejudice. Thus, the UMWA's miner certification campaign was consistent with the view, already entrenched in the community and in the law, that accidents were caused by differences among miners, not by unsafe working conditions.

22 See note 18

23 At this time in other parts of the United States, personal injury cases 
brought to mind a class of attorneys who made a living by "ambulance chasing," that is, attorneys forced by their limited competence and marginal incomes to obtain clients by using ethically questionable means to persuade victims of injury to litigate (Auerbach 1976). But there was no underclass of lawyers in southern West Virginia. Instead, as explained in the text, the chief plaintiffs' lawyer in industrial accident litigation in Fayette County after $\mathbf{9} 900$ was also the leading criminal defense attorney, C. W. Osenton.

24 During this period there was no substantial change in the application of the two major common law legal doctrines that barred recovery by employees for work-related injuries: the fellow servant rule and the doctrine of assumption of risk. The first barred recovery for accidents that could be attributed to the negligence of another employee, on the theory that the proper defendant was the other employee, not the employer. The second doctrine held that an employee with foreknowledge (including imputed knowledge) of risks associated with a job agreed to undergo those risks without compensation for injury. The continued harshness of the effects of these rules is confirmed by the proceedings of a State Bar Association meeting in I9IO at which attorneys discussed proposals for workmen's compensation legislation.

25 In I900 there was a major explosion in the Red Ash mine, and in I907, 86 died in the Stuart mine explosion. Major explosions were a reminder to the public of the constant risk faced by miners, but smaller fatal accidents that went unreported by newspapers were frequent.

\section{REFERENCES}

Asher, Robert (1986) "Industrial safety and labor relations in the United States, I865-I917," in Charles Stephenson and Robert Asher (eds.) Life and Labor: Dimensions of American Working-Class History. Albany: State University of New York Press: I I5-30.

Athey, Lou (I990) "The company store in coal town culture." Labor's Heritage 2: 4-23.

Auerbach, Jerold (1976) Unequal Justice: Lawyers and Social Change in Modern America. New York: Oxford University Press.

Charleston Gazette ( 1895 ).

Cohen, Joshua, and Joel Rogers ( 1983) On Democracy: Toward a Transformation of American Society. New York: Penguin Books.

Corbin, David ( 198I ) Life, Work, and Rebellion in the Coal Fields: The Southern West Virginia Miners, I880-I922. Urbana: University of Illinois Press.

Eller, Ronald D. ( I982) Miners, Millhands, and Mountaineers: Industrialization in the Appalachian South, I880-1930. Knoxville: University of Tennessee Press.

Engel, David (1984) “The ovenbird's song: Insiders, outsiders, and personal injuries in an American community." Law and Society Review I8: 55I-82.

Friedman, Lawrence M., and Jack Ladinsky (1967) "Social change and the law of industrial accidents." Columbia Law Review 67: 50-82.

Galanter, Marc ( I974) "Why the 'haves' come out ahead: Speculation on the limits of legal change." Law and Society Review 9: 95-I60. 
Genovese, Eugene (1974) Roll Jordan Roll: The World the Slaves Made. New York: Pantheon.

Graebner, William (1976) Coal Mining Safety in the Progressive Period: The Political Economy of Reform. Lexington: University Press of Kentucky.

Harris, Sheldon ( 1969) "Letters from West Virginia: Management's version of the I902 coal strike." Labor History I0: 228-40.

Horwitz, Morton J. ( 1977) The Transformation of American Law, I780-I860. Cambridge, MA: Harvard University Press.

Kidder, Robert (I980-8I) "The end of the road? Problems in the analysis of disputes." Law and Society Review 15: 717-25.

Lane, Winthrop ( I924) The Denial of Civil Liberties in the Coal Fields. New York: Doran and Co.

Lempert, Richard, and Joseph Sanders ( 1986) An Invitation to Law and Social Science: Desert, Disputes, and Distribution. New York: Longman.

Lubove, Roy (1967) "Workmen's compensation and the prerogatives of voluntarism." Labor History 8: 26I-79.

Lukes, Steven ( 1974) Power: A Radical View. London: Macmillan.

Macaulay, Stewart ( 1963 ) "Non-contractual relations in business: A preliminary study." American Sociological Review 28: 55-67.

_ (I985) "An empirical view of contract." Wisconsin Law Review 3:46582.

(1966) Law and the Balance of Power: The Automobile Manufacturers and Their Dealers. New York: Russell Sage Foundation.

- (1977) "Elegant models, empirical pictures, and the complexities of contract." Law and Society Review I I: 507-28.

Mackinnon, Catharine A. (I982) "Feminism, Marxism, method, and the state: An agenda for theory." Signs: A Journal of Women in Culture and Society 7: $515-44$.

Massey, Glenn F. ( I970) "Coal consolidation: Profile of the Fairmont field of northern West Virginia, I852-I903." Ph.D. diss., West Virginia University.

Mather, Lynn, and Barbara Yngvesson (198I) "Language, audience, and the transformation of disputes." Law and Society Review I5: 775-82 I .

Mayhew, Leon H., and Albert J. Reiss, Jr. (1969) "The social organization of legal contacts." American Sociological Review 34: 309-I8.

Munger, Frank ( 1987a) "Social change and tort litigation: Industrialization, accidents, and trial courts in southern West Virginia, I872 to I940." Buffalo Law Review 36: 75-1 I8.

- (1987b) "Businesses and litigation in the Progressive Era." Paper presented at the Conference on Longitudinal Research on Trial Courts, Buffalo, 24-27 August.

( I988) "Law, change, and litigation: A critical examination of an empirical research tradition." Law and Society Review 22: 57-IOI .

(forthcoming) "Miners and lawyer: Politics and profession in a rural community," in Christine H. Harrington and Maureen C. Cain (eds.) Lawyers Work. London: Open University Press.

Olson, Mancur (1965) The Logic of Collective Action: Public Goods and the Theory of Groups. Cambridge, MA: Harvard University Press. 
Rude, George (I97I) Paris and London in the Eighteenth Century: Studies in Popular Protest. New York: Viking.

Silverman, Jerry, ed. ( 1975) Folk Song Encyclopedia, vol. I. New York: Chappell Music.

Skowronek, Stephen (1982) Building a New American State: The Expansion of National Administrative Capacities, I877-1920. Cambridge: Cambridge University Press.

Thomas, J. B. ( I97I) "Coal country: The rise of the southern smokeless coal industry and its effect on area development, I872-I910." Ph.D. diss., University of North Carolina at Chapel Hill.

Thompson, Edward P. (1975) Whigs and Hunters: The Origin of the Black Act. New York: Pantheon.

Tilly, Charles (1978) From Mobilization to Revolution. Reading, MA: AddisonWesley.

U.S. Bureau of the Census (19I3) Thirteenth Census of the United States. Vol. I, Population: General Report and Analysis. Washington, DC: U.S. Government Printing Office.

(I922) Fourteenth Census of the United States. Vol. 3, Population. Washington, DC: U.S. Government Printing Office.

(I932) Fifteenth Census of the United States: 1930. Vol. 3, Pt. 2, Population: State Reports. Washington, DC: U.S. Government Printing Office.

U.S. Census Office (I900) "Population of West Virginia by counties and minor civil divisions." Bulletins of the Twelfth Census of the United States, No. 53. Washington, DC: U.S. Government Printing Office.

Wallace, Anthony F. C. ( I987) St. Clair: A Nineteenth-Century Coal Town's Experience with a Disaster-Prone Industry. New York: Knopf.

Weinstein, James ( 1967 ) "Big business and the origins of workmen's compensation." Labor History 8: I56-74.

Wesser, Robert ( I97I) "Conflict and compromise: The workmen's compensation movement in New York, I890s-I9I3." Labor History I2: 345-72.

West Virginia Department of Mines ( I883, I888-1925) Annual Report.

Wiebe, Robert (1967) The Search for Order, 1877-1920. New York: Hill and Wang.

Williams, John A. (1976) West Virginia and the Captains of Industry. Morgantown: West Virginia University Press.

Yngvesson, Barbara (I985) "Re-examining continuing relations and the law." Wisconsin Law Review 3: 623-46. 